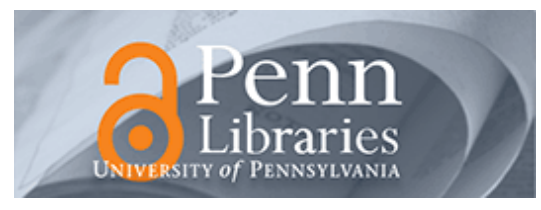

University of Pennsylvania

ScholarlyCommons

6-9-2011

\title{
Agency, Causeways, Canals, and the Landscapes of Everyday Life in the Bolivian Amazon
}

Clark L. Erickson

University of Pennsylvania, cerickso@sas.upenn.edu

Follow this and additional works at: https://repository.upenn.edu/anthro_papers

Part of the Anthropology Commons

\section{Recommended Citation (OVERRIDE)}

Erickson, C. L. (2009). Agency, roads, and the landscapes of everyday life in the Bolivian Amazon. In J. Snead, C. Erickson, \& A. Darling (Eds.), Landscapes of movement: Trails, paths, and roads in anthropological perspective (pp. 204-231). Philadelphia: Penn Museum Press and the University of Pennsylvania Press.

This paper is posted at ScholarlyCommons. https://repository.upenn.edu/anthro_papers/2

For more information, please contact repository@pobox.upenn.edu. 
Agency, Causeways, Canals, and the Landscapes of Everyday Life in the Bolivian Amazon

Disciplines

Anthropology | Social and Behavioral Sciences 


\section{LANDSCAPES of MOVEMENT Trails, Paths, and Roads in Anthropological Perspective}

EDITED BY

James E. Snead

Clark L. Erickson

J. Andrew Darling

University of Pennsylvania Museum of Archaeology and Anthropology

Philadelphia 


\title{
Agency, Causeways, Canals, and the Landscapes of Everyday Life in the Bolivian Amazon
}

\author{
CLARK L. ERICKSON
}

B uilt environment provides an excellent medium for addressing issues of space, place, landscape, agency, flow, circulation, and interaction of human agents within physical structures laden with cultural, social, political, economic, and symbolic meaning (e.g., Atkin and Rykwert 2005; Lawrence and Low 1990; Low and Lawrence 2003; Moore 2005). The concept of built environment addresses issues of aesthetics, design, planning, function, and meaning of architecture. Traditionally, built environment meant formal buildings, monuments, and cities, although in more recent years, vernacular architecture and landscape are included. Because built environment is often highly patterned and physical, a form of material culture or human artifact, archaeologists can document, analyze, and interpret its origins, function, evolution, and meaning in much the same way as traditional objects of archaeological study are employed to understand the past.

In this chapter, human agency and structure that are embedded in the cultural or anthropogenic landscape, a particular form of built environment, are examined through practice theory. My research focuses on mundane landscapes, the landscapes of everyday life including farming, daily economic activities, routines of work and sociality. These environments have been transformed to such an extent through applications of technol- 
ogy and mobilization of human labor and energy that I refer to them as anthropogenic or engineered landscapes. Although often ignored in favor of large urban centers and monumental sites, these cultural landscapes are as constructed and planned as formal architecture anywhere on Earth. I document the patterned practices of everyday life that are physically embedded in a precolumbian and historical cultural landscape of the Baures Hydraulic Complex in the Bolivian Amazon. In this case study, ubiquitous landscape features such as causeways and canals provide a means of understanding complex landscapes of movement and social interaction through the perspective of practice theory and landscape.

\section{AGENCY AND STRUCTURE IN CULTURAL LANDSCAPES}

Pierre Bourdieu's (1977) practice theory stresses the dynamic relationship between the agency of individuals and groups and structure, the interface of which he labeled habitus. Bourdieu's concept of habitus is particularly relevant to archaeology because of his focus on the built environment, space, and the practices of everyday life (e.g., Barrett 2001; Bintliff 2004; Dobres and Robb 2000, 2005; Dornan 2002; Joyce and Lopiparo 2005; Llobera 1996, 2000; Smith 2001; Robin 2002). Bourdieu's original case study was the Berber house, a highly structured physical entity that is both a model of and a model for society. Human individuality and creativity produces cultural innovations that can become habitus (or structure) if adopted in human routines of life. Over time, habitus become an active force for shaping human activity. In turn, individual agents through daily practice can alter those structures of everyday life.

The complex recursive relationship between practice and structure creates the patterns that we recognize in the archaeological record and identify as aspects of long-term traditions; local, regional, and cross-cultural variation; and continuity and change over short and long temporal scales. Landscape is a valuable medium to read the nuances of practice, agency, structure, and habitus. Landscape archaeologists read the physical, patterned "residues" of accumulated human routines and practical knowledge or habitus. We do landscape archaeology through recognition of context, association, pattern, continuity and discontinuity, anomaly, palimpsest, landscape capital, inhabitation, and historical ecology (Anschuetz, Wilshusen, and Scheick 2001; Ashmore and Knapp 1999; Balée and Erickson 2006; Wilkinson 
2003). With fine-grained analysis, even ephemeral patterning is detectable. Anomalies and disjunctures reveal discrete agency and spatial and temporal groupings and boundaries, which often relate to socio-political organization on the ground or changes over time (e.g., Erickson 1993; Walker 2004).

Trails, paths, and roads may be the best built environment media for highlighting the contributions of the archaeology of landscapes due to their materiality, longevity, permanence, patterning, and multiple functions and meanings. Trails, paths, and roads connect people to people, people to resources, or in the case of ritual roads and pilgrimage, people to their gods and sacred places. As complex networks of human relationships, routes map communication, transportation, interaction, and social, political, economic organization (e.g., Ingold 1993; Tilley 1994, 2004; Wilkinson 2003). On the other hand, where trails, paths, and roads do not go can demarcate territories and boundaries between groups occupying the same landscape. The multiscalar thinking about time and space in a landscape approach is relevant for understanding the archaeology of movement, which can include anything from local short-term events to regional phenomena with deep histories and beyond. The size and complexity of movement network may reflect the scale and intensity of interaction (Earle, Chapter 12, this volume; Appendices 1 and 2). Short, ephemeral trails and paths and circulation within households may relate to individual or small group activity (e.g., Robin 2002; Stahl and Zeidler 1990). In contrast, nested, bounded networks of road communication may reflect either hierarchical or heterarchical organization of society (e.g., Crumley 1995; Crumley and Marquardt 1987). In other cases, vast networks of informal trails and paths of small, relatively non-complex societies may cover entire regions, subverting assumptions about scale and socio-political stages (Snead 2002, Chapter 3, this volume; Darling, Chapter 4, this volume). In addition to mundane practical everyday use, trails, paths, and roads may serve important functions of performance during processions, rituals, and pilgrimage (e.g., Abercrombie 1998; Bauer 1998; Inomata and Coben 2006; Moore 2005; Morrison 1978; Ferguson, Berlin, and Kuwanwisiwma, Chapter 2, this volume; Keller, Chapter 7, this volume). Approaches to the archaeology of movement range from descriptions and functional analyses of trails, paths, and roads, often through the lens of process, political economy, evolution, and cultural ecology (e.g., Espinoza 2002; Hyslop 1984; Kantner 1997; Oyuela 2000; Wilkinson 2003; Ur, Chapter 9, this volume) to studies of the interpretation and meaning 
of these features framed in phenomenology, practice, memory, interpretation, and semiotics (e.g., Aveni 2000; Chadwick 2004; Keller, this volume; Llobera 1997, 2000; Snead and Preucel 1999; Sofaer, Marshall, and Sinclair 1989; Tilley 1994, 2004). As the result of intentional activities of everyday life, repetitive movement creates physical structure over time. Once established, this highly patterned structure often determines later activities through features that facilitate and impede movement. Because of this recursive relationship, trails, paths, and roads can be models of and for society or Bourdieu's habitus.

The practices of everyday life and social interaction, in particular human movement through space, simultaneously create and are structured by the built environment and cultural landscape. Repetitive bodily movement through space and the physical structures that result from and channelize this movement create a tight recursive relationship. Places determine networks of movement and these networks structure new places. Informal movement creates paths and trails, which over time, grow and become more complex through accretion and formalization. Although "entrenched" over time, these movement networks can be transformed through changing needs, new technology, and the shifting of places of origin and destination. Although movement through already established routes is often unconscious, circulation through most space involves decision making (consideration of slope, natural obstacles, least resistance, and other physical contingencies of movement), negotiation (where you can and you cannot go because of neighbors, land tenure, and other social contingencies of movement), and meaning (the aesthetics, symbolism, ideology, metaphor, and other interpretations of movement). In extreme cases, movement can be highly structured through designed roads, bridges, and stairs that facilitate and direct traffic and walls, barriers, gates, and other cultural obstructions that impede or control circulation.

\section{THE ENGINEERED LANDSCAPES OF THE BAURES REGION OF BOLIVIA}

The Baures Region is a remote corner of the Llanos de Mojos (Moxos), a vast landscape of seasonally inundated grassland savannas, permanent wetlands, lakes, gallery forests, forest islands, and closed canopy forest in the Amazon Basin of northeast Bolivia (Figure 10.1). Much of the country is 
submerged beneath a thin sheet of water during the wet season. Rivers and lakes are filled with fish and other aquatic species throughout the year and migrate across the savannas during floods. The flooding of the wet season is in sharp contrast to the dry season when water can be scarce. Scattered "forest islands" rise a meter or two above the surrounding savanna, ranging in size from several hectares to many square kilometers and sustaining settlements, ranches, gardens, and fields within the populated areas to the north and west. Unlike the anthropogenic (human created) forest islands in central Bolivian Amazon, those in the savannas of Baures Region are natural formations produced by upwelling of the Brazilian Shield.

The Baure probably were the last indigenous group to be subjugated by

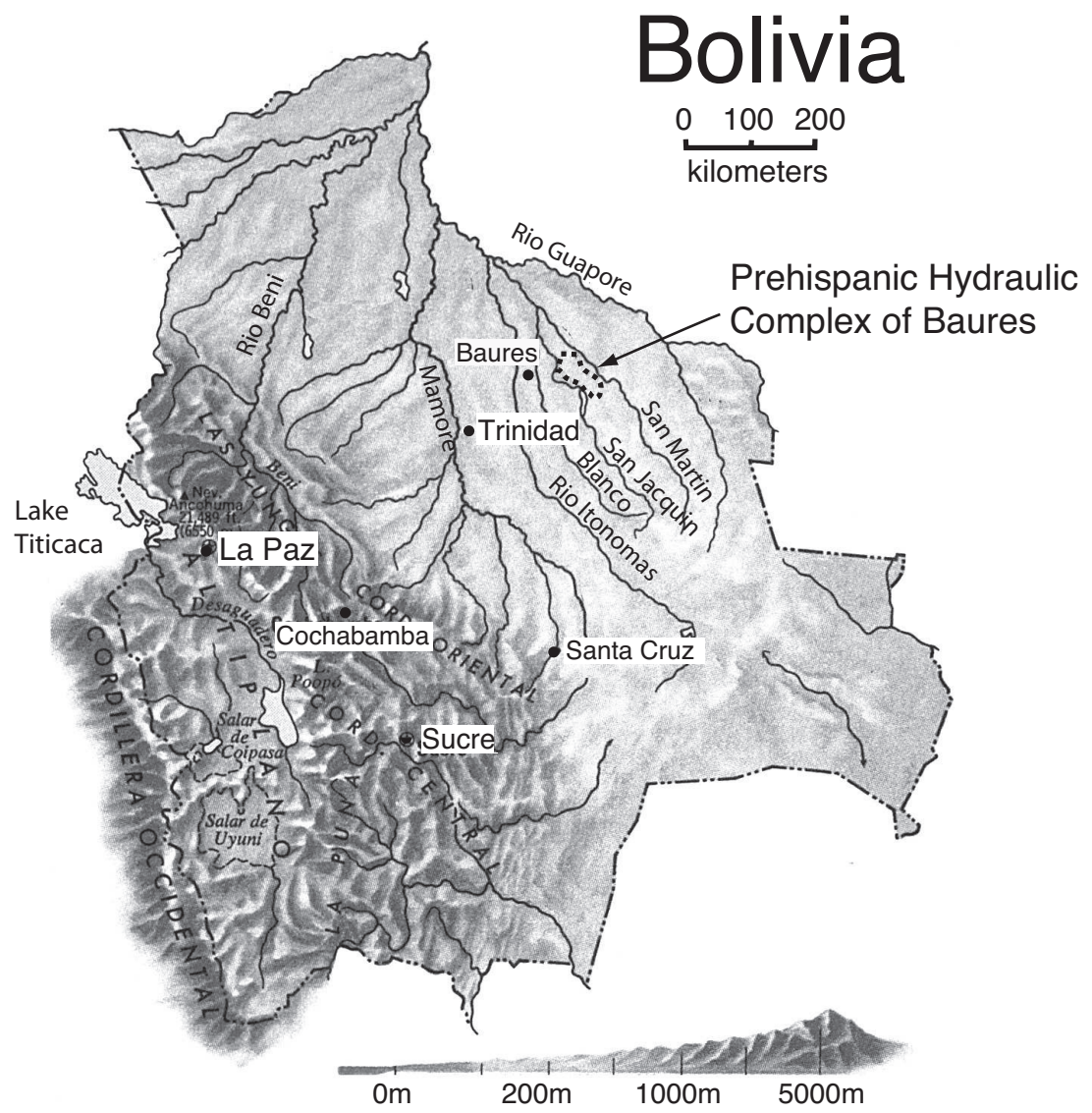

10.1 The Bolivian Amazon. 
the Spanish in Bolivia. After a brief bloody retribution by the Spanish army for killing their first missionary, the Jesuits established control in the early 1700s. The Jesuits were impressed by what they recognized as a remarkable civilization: elaborate dress, large settlements, political organization, intensive agriculture, and monumental earthworks associated with the Baure people (Anonymous 1743; Eder 1888, 1985; Métraux 1942; Denevan 1966, 1991; Block 1994). Baure settlements were distributed in the Itonama, Blanco, Negro, San Joaquin, San Martin, San Simon, and Itenez (Guaporé) river drainages. In addition to groups speaking dialects of Baures (Baure, Muchojeone, and Paikoneka), smaller dispersed groups such as the Sirionó, Itonama, and Guarasug'we also occupied the Baures region. Population was estimated to be 40,000 dispersed in 75 to 124 large settlements (Altamirano 1891:117; Block 1994; Denevan 1966; Eguiluz 1884:22). Over time, native populations sharply declined due to Old World diseases, wars with the Portuguese, slavery, and other abuses following the expulsion of the Jesuits and later during the Rubber Boom and Chaco War. While some successful Jesuit mission towns such as Concepción de Baures continue to the present, many failed and were abandoned during the Mission Period.

I use the term "Baure" for the contemporary, Colonial, and precolumbian native peoples of the region, "Baures" for the mission and contemporary administrative center town, "Baures Region" for the areas of archaeological features and contemporary occupied landscape (Figure 10.1), and "Baures Hydraulic Complex" (BHC) for the engineered landscape in the savannas between the San Joaquin and San Martin rivers (recognized as the Kenneth Lee Archaeological Reserve by the National Government of Bolivia) (Figure 10.2).

The inhabitants of the Bolivian Amazon imposed their agency and structure on the environment through permanent and significant engineering. Various scholars have highlighted the importance of causeways and canals (CEAM 2003; Denevan 1966, 1991; Erickson 1980; Métraux 1942; Michel 1993; Pinto Parada 1987; Plafker 1963; and specifically for the Baures region: Orbigny 2002; Lee 1979, 1995; Nordenskiöld 1916, 1918, 2001; 2003). Various sites in Baures, Magdalena, Bella Vista, and along the Itenez/Guapore River were briefly investigated by archaeologists (Becker-Donner 1956; Calandra and Salceda 2004; Denevan 1966; Dougherty and Calandra 1981, 1983, 1984; Kelm 1953; Prümers 2006; Prümers, Betancourt, and Plaza 2006; Reister 1981). As part of the Agro-Archaeological Project of the Beni (University of 


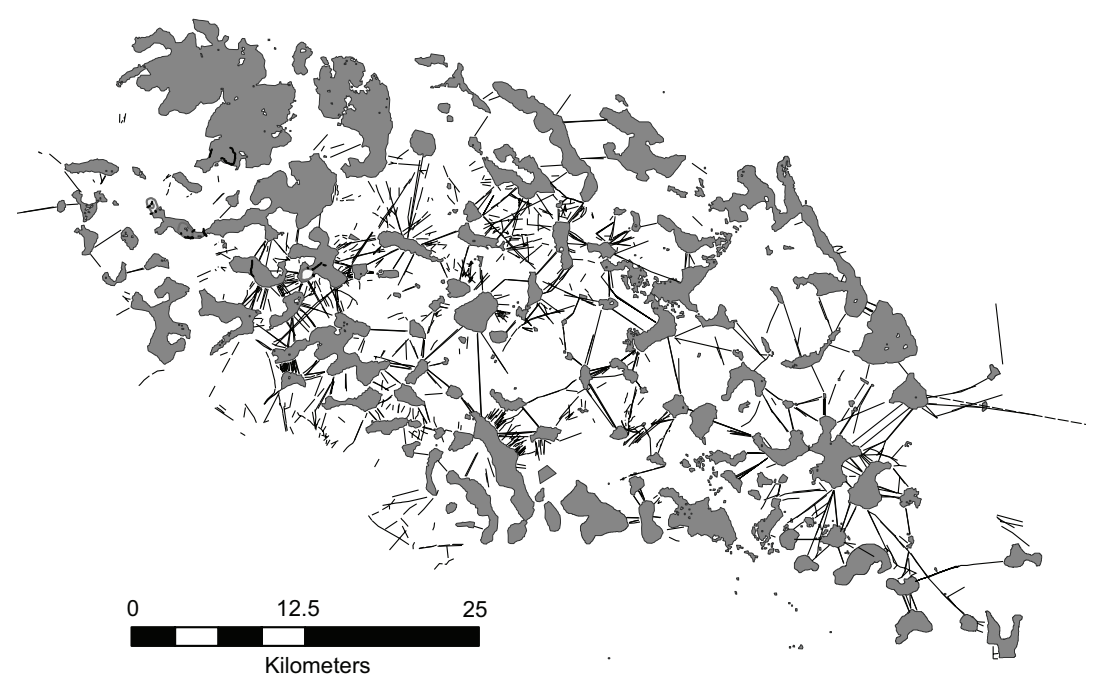

10.2 Major Causeways-Canals, Minor Causeways-Canals, and forest islands in the savannas of the Baures Hydraulic Complex, Bolivia.

Pennsylvania and National Institute of Archaeology), we investigated sites and earthworks including raised fields, fish weirs, water management structures, settlements, artificial river meander cut-offs and inter-river channels, causeways, and canals between 1995 and the present (Erickson 1995, 2000a, 2000b, 2000c, 2001, 2002, 2006a; Erickson et al. 1995; Erickson, Winkler, and Candler 1997; Vranich 1996).

\section{MAPPING AGENCY AND STRUCTURE IN A LANDSCAPE OF MOVEMENT}

The study region is unpopulated today; thus, the earthworks are remarkably well preserved in contrast to areas subject to heavy cattle grazing. All surveyed forest islands larger than $1 \mathrm{~km}^{2}$ have ring-ditch sites of diverse size and shape: octagons, hexagons, squares, rectangles, "D" shapes, circles, ovals, and irregular shapes (Erickson 2002, 2006a, 2008; Erickson, Winkler, and Candler 1997; Vranich 1996) (Figure 10.3). Large forest islands have multiple, evenly spaced, ring-ditch sites. Ditches are often several meters deep and steep sided and some extend 1-2 linear $\mathrm{km}$ and include multiple concentric rings. The Jesuits described these features as forts with deep 


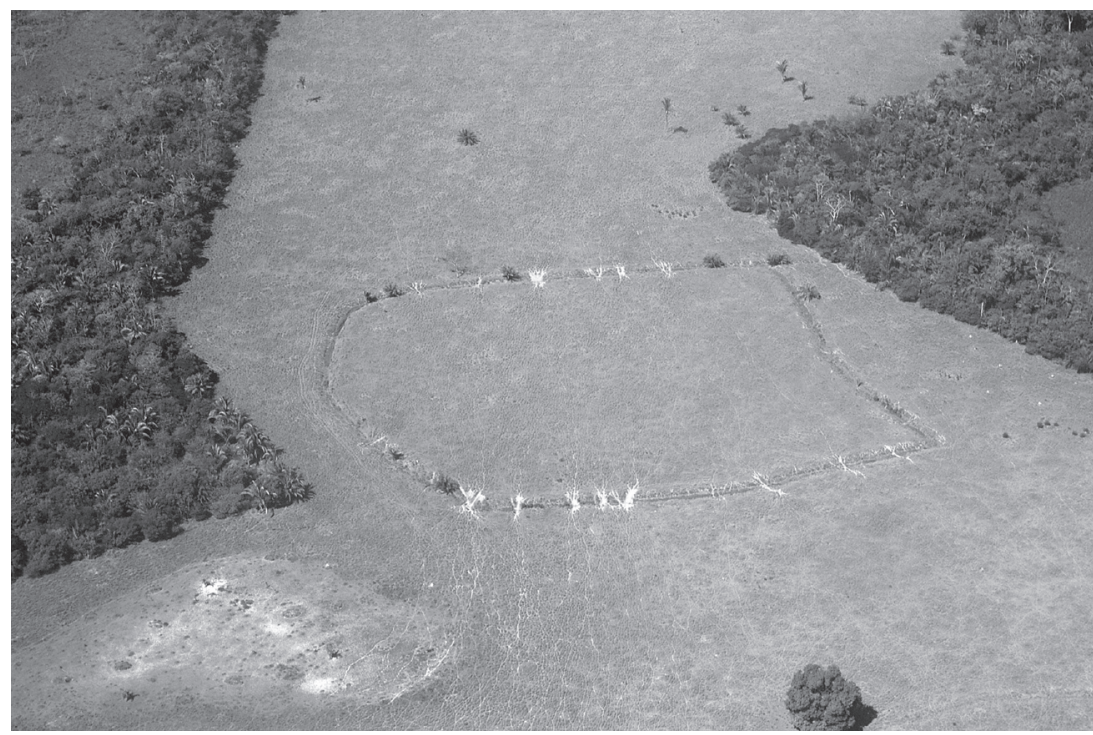

10.3 D-shaped ring-ditch site at the Buen Retiro Ranch, Bolivia.

moats and palisades (Anonymous 1743; Eder 1985) (Figure 10.4). Although few have been investigated archaeologically, ring-ditch sites may have been cemeteries, sacred spaces, elite residences, settlements, and/or defensive structures. These features also are documented for Riberalta, Bolivia (Arnold and Prettol 1989), and the Acre and Upper Xingu river regions of Brazil (Heckenberger 2005; Pärssinen and Korpisaari 2003).

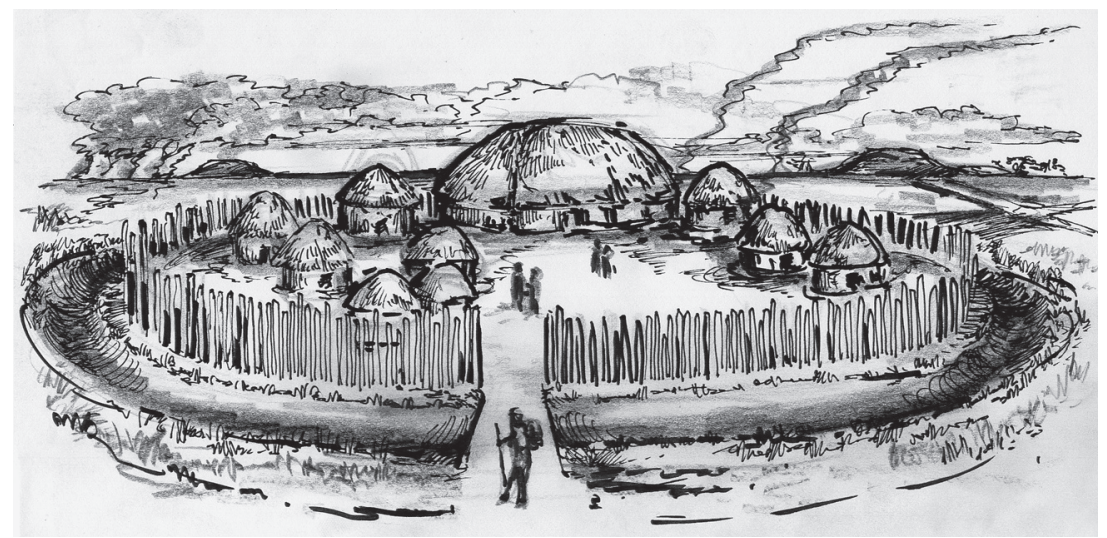

10.4 Reconstruction of a ring-ditch site. (Artwork by Daniel Brinkmeier) 
Although similar in shape and scale to the large circular villages with central plazas of the Central and Eastern Amazon basin (Wust and Baretto 1999; Heckenberger 2005, 2008), the ring-ditch sites of the Baures Region, Riberalta, and the Acre region tend to lack evidence of domestic activity, which suggests non-residential use. The Jesuits were impressed by the larger settlements, but also describe dispersed, dense occupation throughout the forest islands. As an early strategy of control and indoctrination, the Jesuits resettled peoples in their new mission towns, a settlement system that continues today. Archaeologically, settlements are difficult to document due to thick vegetation and soil cover and the ephemeral nature of Amazonian residential structures. Today, individual households often maintain several houses in different locations for farming and resource collection.

A vast network of raised earthen causeways and canals provided a landscape of movement to connect these important places. A causeway is defined as a formal, intentionally raised road, usually of locally obtained earth. A canal is an intentionally excavated linear feature intended to hold water seasonally or permanently or simply the result of building causeways. Causeways and canals are usually associated as combined landscape features in the BHC. Causeways and canals vary in length from tens of meters to many kilometers. Most causeways and canals are straight. Many form radial patterns from a common source, usually located on a forest island. Most causeways and canals are associated with low-lying, seasonally or permanently inundated savannas or wetlands, although some penetrate the higher ground of forest islands. Causeways and canals can be divided into Major and Minor types based on scale, energetics, design, and context.

Major Causeways are highly visible as tree-lined features flanked on one or both sides by canals filled with dark aquatic vegetation, which stands out against the grass-covered savanna (Figure 10.5). The adjacent water-filled canals block annual savanna burns, allowing trees to flourish on causeways after abandonment. Major Causeways range in width from 1 to $10 \mathrm{~m}$ and elevations vary from 0.5 to $3 \mathrm{~m}$ tall; Major Canals are comparable in dimensions. Most Major Causeways-Canals are straight and extend up to $7.5 \mathrm{~km}$, although most are several kilometers long. Pedestrians used the elevated causeways and canoe traffic circulated in the adjacent canal(s) (Erickson 2000a, 2000c, 2001, 2006a; Erickson and Walker, Chapter 11, this volume). Major Causeways-Canals represent the longest inter-forest island connec- 


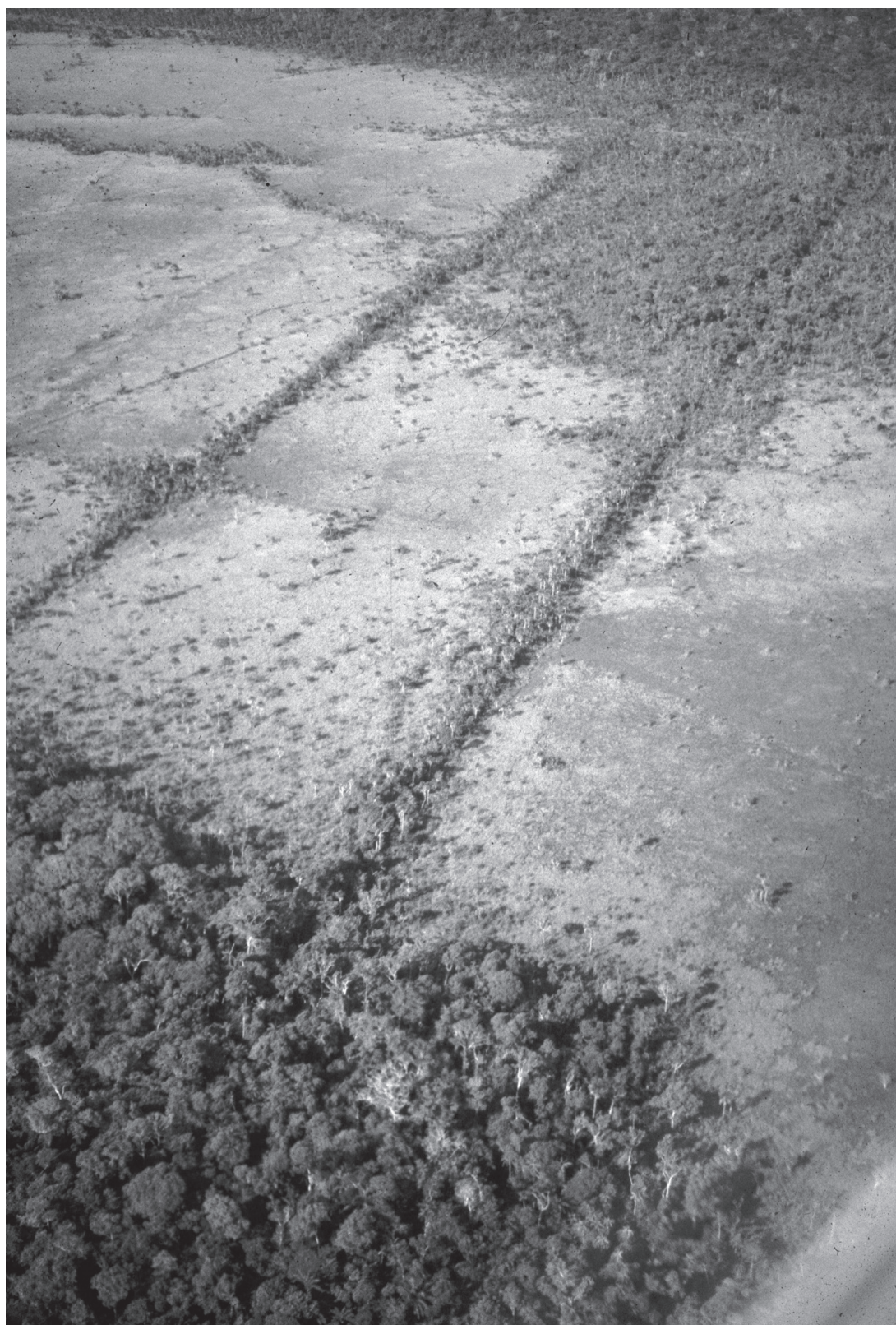

$\oplus$

10.5 Tree-covered parallel Major Causeways-Canals crossing the savanna between forest islands. 
tions. These works often are monumental in design, labor, and scale; most appear on satellite imagery from space and are formal roads. Some are particularly labor intensive in scale of earth moved and we recorded many double and triple parallel causeways-canals (Figure 10.5). Construction was done using simple wooden digging sticks and earth moved in baskets and/ or carrying cloths.

The more common Minor Causeways-Canals were also laid out in straight alignments but are shorter in length and required less construction than the Major Causeways-Canals. These features consist of a single shallow canal ( $1 \mathrm{~m}$ wide and less than $0.5 \mathrm{~m}$ deep) with low causeways or berms alongside ((Figure 10.6). My informant-guides and I interpret these shallow canals as precolumbian canoe paths: channels for paddling or poling large canoes across the shallow inundated savanna during the wet season. During the dry season, the channels could be used as routes for pedestrian traffic through savanna grasses. Repeated paddling, poling, or dragging a large canoe through the shallow water can create canal-like depressions over time with minimal planning or labor (Figure 10.7). The irregular scar of annual

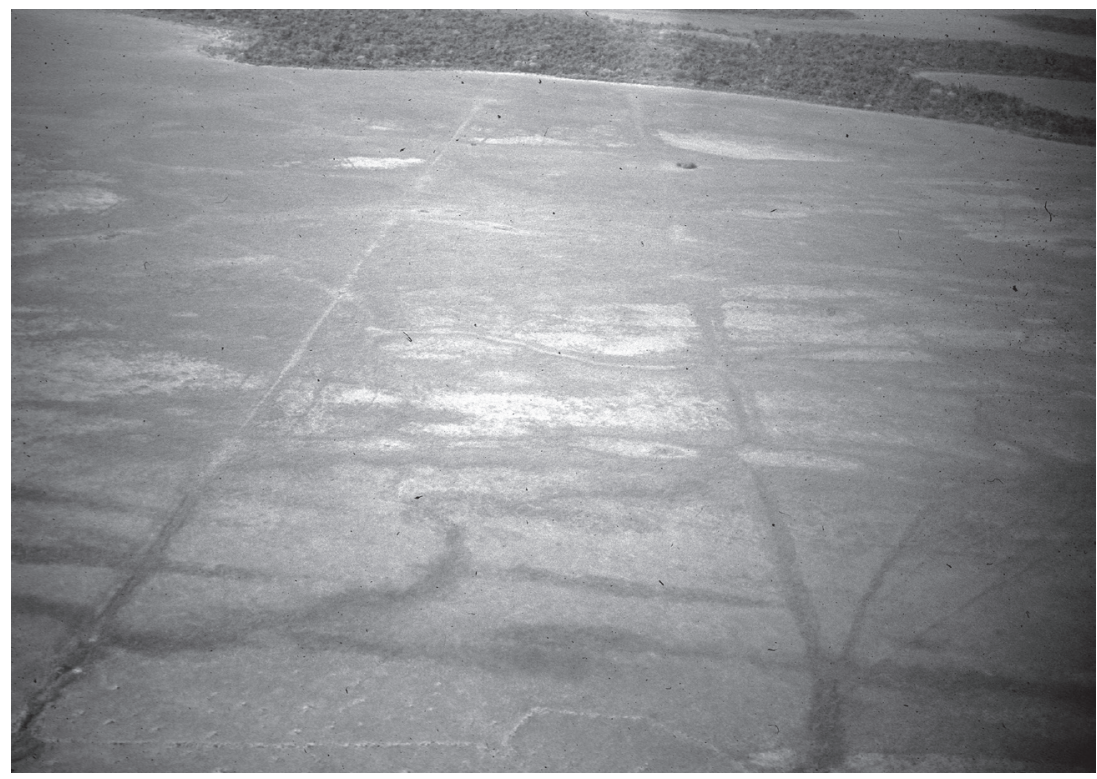

10.6 Minor Causeway-Canal or canoe path (dark line) crossing the savanna in tall grass between Largo and Paralelo forest islands. 


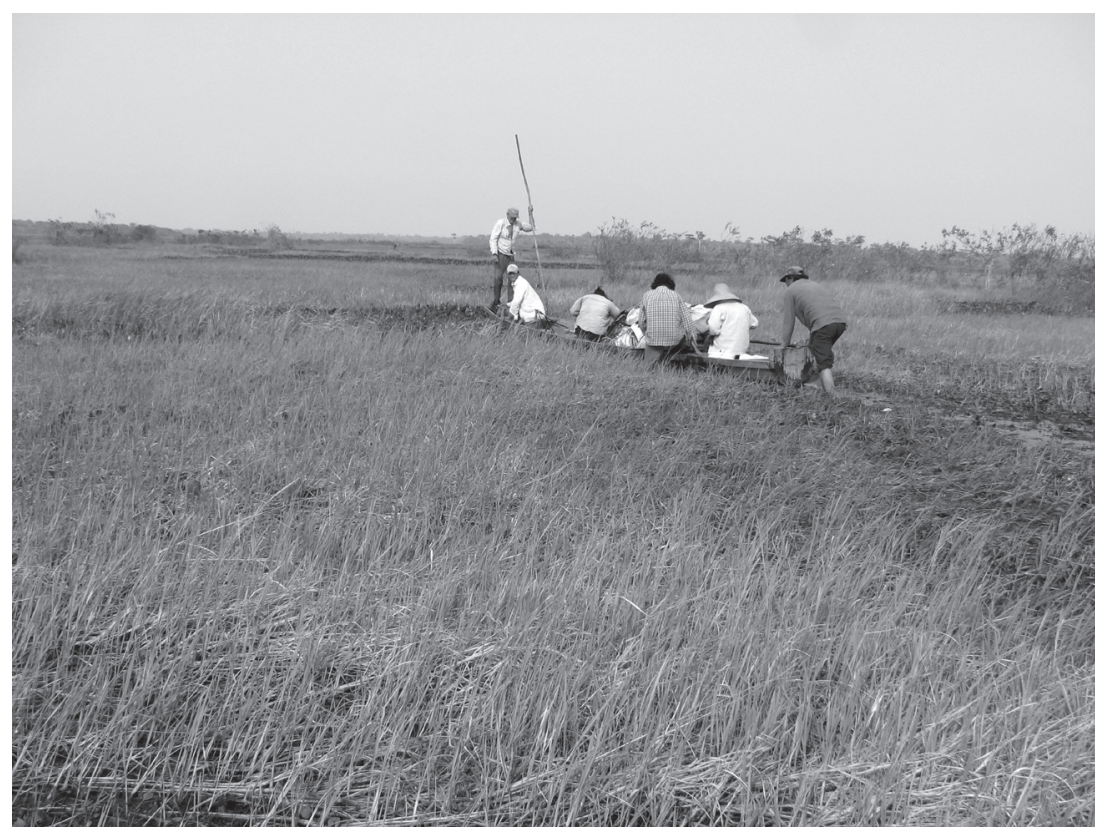

10.7 Poling and paddling a large dugout canoe across the flooded savanna of the Baures Hydraulic Complex.

canoe transit of my native guides is a good example of what a few hunters can do through even irregular routines over many years. Their paths have been permanently etched on the landscape as a modern layer of palimpsest. I can trace their recent canoe path across the savanna to their forest island camp on satellite imagery, a distance of $7 \mathrm{~km}$. The sinuous irregular courses of these recent canoe paths stand in contrast to the straight trajectory of Minor Causeways-Canals, which implies concern with trajectory during the initial shallow channel excavation. Although simple constructions, Minor Causeways-Canals share the straightness and precision of layout of the larger Major Causeways-Canals.

The project Geographic Information System (GIS) of the Baures Region includes Digital Elevation Models, Landsat ETM scenes, CORONA images, aerial photographs, topographic maps, and vector maps of cultural features, classified vegetation, and landuse. Numerous flights in low-flying aircraft provided opportunities for oblique photography. Two short seasons of pedestrian survey, mapping, and excavation in the Baures region were con- 
ducted in 1995 and 1996. The GIS documents over 1000 individual artificial linear features representing 994 linear $\mathrm{km}$ in total length (averaging $1 \mathrm{~km}$ ) in the $500-700 \mathrm{~km}^{2}$ of the BHC (Figure 10.2). Most are Minor CausewayCanals. A remarkable concentration of Minor Causeways-Canals is found in a $3-4 \mathrm{~km}^{2}$ area of savanna between and around two large forest islands: the San Martin Forest Island Complex (Figure 10.8). In this small subset of the GIS, I detected 168 linear features, of which the majority are Minor Causeways-Canals of $1 \mathrm{~km}$ or less in length. Eleven Major CausewaysCanals extend to the south and north.

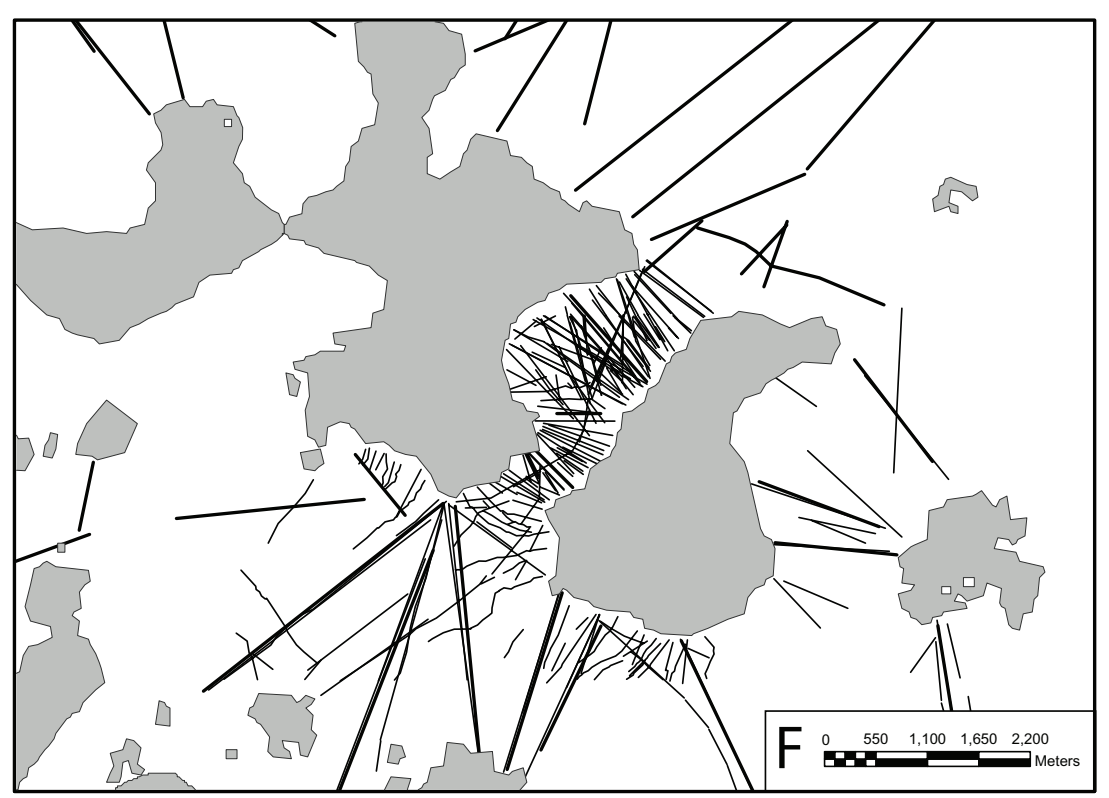

10.8 Major Causeways-Canals and Minor Causeways-Canals of the San Martin Forest Island Complex.

\section{PREHISTORY, ETHNOHISTORY, AND ETHNOGRAPHY OF MOVEMENT IN THE AMAZON}

As agency and structures of everyday life, the causeways and canals of the Baures region can be understood through archaeological context informed by the spatial patterning in the GIS and fieldwork and, to a limited extent, through historical and ethnographic analogy, and comparison to similar 
phenomenon in the Llanos de Mojos and Amazonia. Although archaeological studies of causeways and canals are scarce, trails, paths, and roads are reported for the Amazon region. Large urban settlements with circular plazas bounded by concentric arcs of ditch and embankment that are connected by wide, radial roads of several kilometers in length are documented in the Upper Xingú River basin (Heckenberger 2005, 2008). Located in uplands, these roads are defined by earthen curbs rather than raised roadways and excavated canals. While sharing straightness, radial patterning, and associations with ring-ditch sites, these roads are less numerous, of lower density, and easier to construct than those of the BHC. Archaeologists also have documented a precolumbian network of causeways in the Venezuelan savannas associated with chiefdoms (Garson 1980; Spencer, Redmond, and Rinaldi 1994) and networks of wide curbed roads in the Upper Xingu region (Heckenberger et al. 2008). Although individual causeways and roads are similar in size and length to those of the Baures Region, the network is smaller in geographic scale and of lower density.

Although dispersed settlements, trekking, long-distance trade, reciprocity, and competitive feasting are emphasized in native Amazonian ethnography and history (e.g., Descola 1994; Posey 1983; Rival 2002), scholars have largely ignored the ubiquitous trails, paths, and roads that made this interaction possible. During early exploration along the Amazon River (Solimões River) by the Orellana Expedition of 1541-1542, Carvajal (1988) reported large riverine villages with wide avenues or streets radiating from plazas far into the hinterlands. An early account of the Paresi, a group linguistically related to the Baure, describes long, wide avenues between their many villages (Pires de Campo 1862). Nimuendajú $(1939,1946)$ discussed everyday and special ritual roads used by the Apinayé and the Eastern Timbira for processions, log races, and other rituals associated with initiations and community. Fabian (1992) discusses roads and plazas of the Bororo of Central Brazil as key elements for structuring of cosmological and spatial order.

The Spanish soldiers, missionaries, and colonial authorities observed the use of precolumbian and contemporary causeways and canals in the Bolivian Amazon (Altamirano 1891; Anonymous 1743; Castillo 1906; CEAM 2003; Denevan 1966, 1991; Block 1994; D’Orbigny 2002; Lizarrazú 1906; Marbán 1889; Métraux 1942). Many early Spanish expeditions penetrated the region using the vast network of trails, paths, and roads, most of which were still in use during the Mission Period. Jesuit Father Francisco Eder pro- 
vides a rich eyewitness account of causeways and canals during the Mission Period in the mid-18th century.

$[\mathrm{M}]$ ost of the year the savannas are covered with high water. Boats are the only way to get from one forest island to another. Since most of the natives have no boats (either due to laziness or because they don't know how to make them), but they still find it necessary or enjoyable to go visiting their neighboring friends, usually for the purpose of drinking, they built a certain kind of bridge or dam-like structure of earth by digging a ditch on two sides and piling earth in the middle. These causeways generally remain dry in the floods and are wide enough for Spanish two-horse carriages. The water filled ditches created by their construction are also used for canoes. During the hot dry period and burning of the savannas, these ditches retain enough water so that maize and other goods can be transported. These causeways were mostly used by the Baure tribe; although they are found elsewhere. Nowadays, however, few are in use, partly because the lack of canoes at the disposal of the Indians and partly because after all these years of disuse, the causeways have become ruins. (Eder [1772]1985:104-5; Eder [1772] 1888:36; Boglar and Bognar 1973-81) ${ }^{1}$

The Baure efficiently combined causeways for terrestrial traffic and canals for aquatic circulation into an integrated landscape of movement. While we tend to focus on causeways as platforms for pedestrian movement, Eder clearly points out that canoe traffic in the associated canals may have been more important. Native peoples in this region and throughout Amazonia relied heavily on water transport. The canoe was a key characteristic of Tropical Forest Culture (Lathrap 1970; Lowie 1948). A complex network of natural and artificial waterways connects most of Amazonia with neighboring drainage basins (Nordenskiöld 1916). Canoe travel by Amazonian peoples played a key role in alliances, warfare, slaving expeditions, and trade during the Colonial Period (DeBoer 1986) and contemporary daily life (Smith 1999). The artificial enhancement of water routes through canal digging and river meander cut-offs is well documented (Abizaid 2005; Raffles and Winkler-Prins 2003). In describing the Mojo, Block (1994:23) states that they "lived in their canoes" and an early vocabulary of Mojo Arawak 
"is filled with watery words, including seven separate expressions for river, describing various sizes, colors, and textures." Canoe transportation is still highly valued in the Baures region. My informants and guides repeatedly tell me, "We would rather paddle or pole a canoe than walk any day."

The desire to travel by canoe has shaped the Baures landscape in other major ways. The obsession with straightness was also applied to the vast meandering rivers of the region. Nordenskiöld (1916) and D'Orbigny (2002) documented a number of river meander short cuts or cut-offs and canals, which connect the main channels of adjacent rivers or their headwaters, many of which were still functioning. More recently, additional canals designed to reduce travel time and canoe portage have been documented (Denevan 1966, 1991; Erickson, Winkler, and Candler 1997). My informants state that the historical and modern river cuts are the product of and "owned" by local communities. Erland Nordenskiöld (1916) cited informants who stated that these artificial canals could change mighty river courses over time. In the Baures Region, members of the Tujeré Community excavated a $0.25 \mathrm{~km}$ canal to cut a river meander in 1995 (Erickson, Winkler, and Candler 1997).

Contemporary farmers, hunters, ranchers, and cattle use informal paths to cross the savannas and wetlands, easily recognized by their irregular, sinuous trajectories despite the flat topography and open savanna. Although sometimes producing worn trench-like ruts in the landscape over time, these informal sinuous foot and canoe paths contrast sharply with the straight precolumbian causeways-canals. In travels within the BMC, my guides consider the overgrown Major Causeways-Canals as obstacles where their canoes must be portaged or a canal must be cut through the feature with shovels. In contrast, precolumbian Minor and Major Causeways-Canals rarely cross or intersect, suggesting a memory of and respect for preexisting features when new routes were created or added.

\section{THE CREATION OF A LANDSCAPE OF MOVEMENT}

Obsession with straightness and radial patterns is common in the cultures of the Americas. In the ethnography of the Central Amazon, straight roads are sacred axes of circular plaza villages dedicated to ritual uses such as the log racing of the Bororo and Gê (Nimuendajú 1939, 1946; Fabian 1992), in addition to trails and paths of mundane, everyday travel. The basic func- 
tions of causeways and canals were for transportation and communication: moving people, goods, and information between settlements in the savanna and rivers of the BHC. Canals were particularly useful for moving heavy and bulky agricultural produce from field to settlement and connecting people with resources such as game, fish, construction materials, firewood, and orchards. To move pedestrians or long, heavy canoes between two points in the flat landscapes of the BHC, direct paths are the most effective. On the other hand, constructing ruler-straight formal Major and Minor Causeways-Canals are beyond what is necessary for efficient movement. Other elements emphasize overengineering and expense such as the existence of multiple parallel causeways-canals when a single causewaycanal would suffice. These formal patterns suggest the agency of individuals, families, hamlets, and communities who agreed to create a local and regional infrastructure of direct communication based on a shared aesthetic of intense social interaction, straightness, and order.

The chronology for causeway and canal use begins around 600 years ago in the Central Bolivian Amazon (Erickson 2000c). We have a single corrected radiocarbon date ranging from AD 1490-1630 for a Major CausewayCanal in the BHC (Erickson 2000c; Erickson, Winkler, and Candler 1997). ${ }^{2}$ Based on these dates and palimpsest and context of earthworks, most Major and Minor Canals-Causeways probably were built and used in the late precolumbian or protohistoric periods before Spanish conquest and missionization of Baures in the early 1700s. With the introduction of Old World diseases, slavery, and wars between Spain and Portugal over this region, native populations collapsed, the region was depopulated, and the earthworks were largely abandoned.

How did the landscape of the BHC come to be and how does the historical process inform us about agency and structure? Despite our lack of direct dates of earthworks and settlements, the GIS shows a complex historical process of landscape formation that can be "read" through palimpsest and patterning. Superposition, intersection, and disjuncture of landscape features across space give us clues to help to sort out the complex construction of this built landscape. In particular, the rare intersections where earlier earthworks are "cut through" by the construction of later features provide clues about chronology and use. When this evidence is present, we can assume that either gradual replacement is occurring or some earthworks have fallen into disuse. 
The straightness and uniformity of individual Major and Minor Causeways-Canals also argues for a single construction episode. The lack of evidence of segmental or incremental construction of individual Major and Minor Causeways-Canals is additional evidence of overall design and structure on the landscape. Straight Major and Minor Causeways-Canals were planned from the beginning. Few, if any, irregular paths, trails, or canoe paths can be dated through palimpsest as precolumbian. The cutting of these straight features by recent irregular trails and canoe paths suggests a disjuncture in patterns of movement. Thus, Minor and Major CausewaysCanals predate the modern features. Most are recently created by seasonal hunters and wild animals such as peccaries, agouti, deer, and tapirs moving between forest islands parallel to the overgrown earthworks, thus are not the evolutionary predecessors of the more formal features.

We find no evidence of mistakes, corrections, and/or experimenting in the design and patterning. The Major and Minor Causeways-Canals appear fully developed on first appearance and throughout their construction and use. The formal design emphasizing precision and straightness applies to all levels of the landscape of movement from Minor Causeways-Canals representing the efforts of individual households living in dispersed hamlets to the Major Causeways-Canals of large communities and supra-communities living in villages and towns and possibly a polity at the regional scale. A shared belief in structure clearly dominated formation of this landscape from the beginning and was passed down through generations as memory, inhabitation, and landesque capital (discussed below).

The majority of the Major and Minor Causeways-Canals do not cross or intersect their neighbors (Figure 10.2). The predominant radial pattern of the Major Causeways-Canals insures autonomy. When Major CausewaysCanals intersect, one usually terminates at the juncture, indicating contemporary use and respect for preexisting structures. Because of their number and density such as the San Martin Forest Island Complex, Minor Causeways-Canals are more likely to intersect, especially where crowded on the landscape (Figure 10.8). Their more ephemeral nature and simple construction suggests that these features regularly went in and out of use according to the needs of individual households, in contrast to the Major Causeways-Canals, which are more permanent and used by larger groups of people. The palimpsest relationship between Major and Minor CausewaysCanals provides details about the creation process of the landscape. The 
cases of Major Causeways-Canals intersecting ("cutting through" and physically perforating) Minor Causeways-Canals outnumber cases of the reverse. Thus, the Major Causeways-Canals were built after the establishment of many Minor Causeways-Canals, but the evidence also suggests overlap in use period.

Earthwork construction profoundly transforms soils, water, and vegetation in highly patterned ways. The design and construction process is "additive" in that, once established, earthworks are permanent. Major Causeways are literally additive in that earth is piled up to create them. Minor Causeways-Canals are superimposed on earlier features as palimpsest, much like a messy, unerased blackboard. Although the features are eroded remains today, we have no evidence of removal of earthworks through destruction, leveling, or erasure. Thus, established earthworks do not disappear through disuse and abandonment, but rather become landscape features of "inhabitation" (e.g., Barrett 1999a) whereby the occupants of the landscape at any point in time are surrounded by and immersed in the works of their ancestors. This inhabitation has important implications for long-term memory, local history, a sense of pride, place, and community, agency, and structure. As an additive or accumulating landscape, the BHC was continually under construction and undergoing a "filling" process that has implications for agency and structure. Certain rules of design were respected during the complex process of landscape creation. Whether the avoidance of building new Major Causeways-Canals across preexisting features reflects respect for past tradition and structure, or simply a decision to save time and energy by not dismantling old features is difficult to determine. Both choices show the increasing dominance of multigenerational group structure over individual agency as the landscape becomes filled. Through accumulation of generations of labor into permanent landesque capital (Erickson and Walker, Chapter 11, this volume), the built environment appears overengineered. The occupants built more Major CausewaysCanals than necessary, often double, triple, or parallel and many are wider and taller than needed for a society without wheeled vehicles and draft animals. Their sense of order and magnitude in the landscape approaches a monumentality commonly associated with more ostentatious complex societies (Trigger 1990).

Despite sharing straightness, individual Major Causeways-Canals vary greatly in terms of length, width, and height. Although common in the 
BHC, complexes of radial Causeways-Canals show little similarity in number of rays, orientation, and scale. This supports the idea that individual Major and Minor Causeways-Canals were planned according to a [shared] structure in mind, builders had considerable leeway in the execution and imposed their agency accordingly. These variations also support a more bottom-up construction and organization of the earthworks.

The numerous and repetitive Minor Causeways-Canals may be the result of long-term landscape-accumulation as households migrated across space through deaths, house replacement, fissioning of communities, and population growth; thus, Minor Causeways-Canals would have been abandoned and replaced as needed. Amazonian houses are impermanent structures that need maintenance and replacement; the lifespan of a typical Amazonian house is short due to post and thatch decay. The dispersed households and multifamily hamlets documented in the ethnographic record outside of permanent villages and towns are relatively ephemeral, thus new Minor Causeways-Canals were created as settlements cycled around the forest islands and provide more evidence of occupation than the ephemeral settlements themselves.

\section{LANDSCAPE MOVEMENT AS A MAP OF SOCIAL INTEGRATION AND ORGANIZATION}

The causeways-canals of the BHC represent engineered networks for social interaction. Their linear patterning stands in sharp contrast to natural formations. Even the animal paths that wander between forest islands often follow or are determined by what humans created. The irregular paths, trails, and roads of modern everyday life that crisscross the occupied areas around the town of Baures and surrounding forest islands stand in sharp contrast to the highly ordered precolumbian landscape. Although the informal would have been easier to create and maintain, the precolumbian peoples apparently preferred more orderly, formal circulation and structure. The number and patterning of Minor Causeways-Canals show a strong desire of individual agents to directly connect with neighbors and a rich sphere of social interaction.

Major Causeways-Canals, characterized by their impressive number, length, width, volume of earth, and straightness, were a visible form of monumentality and a means to show community labor, pride, and aesthet- 
ics. Construction of these overengineered, larger, and more elegant features may have been driven by healthy competition between communities. In the ethnographic and historical record for Amazonia, the social, political, economic, and ritual organization of complex and non-complex societies is based on dynamic and delicate balancing of alliance, competitive feasting, labor reciprocity, trade, host-guest asymmetry, raiding, and warfare (e.g., DeBoer 1986, 2001; Heckenberger 2005; Lathrap 1970; McEwan, Barreto, and Neves 2001). The Jesuit Father Eder ([1703] 1985) complained about the Baure use of causeways for visiting and drinking with friends, an activity that he considered wasteful and unproductive.

All activities rely on physical connections linking people face to face across the landscape. The vast network of causeways and canals probably facilitated and solidified these social processes. Many Major Causeways-Canals lead to or radiate from ring ditches on the larger forest islands, suggesting integrated design and the special ritual function of social gatherings. By directing the eye to the distant horizon on a near flat landscape or convergence on key forest islands, Major Causeways-Canals provide a powerful phenomenological experience even today (Figure 10.9). Major Causeways-Canals may have been elegant, wide tree-lined avenues when in use, further emphasizing a sense of monumentality and order. Equally impressive are three clearly

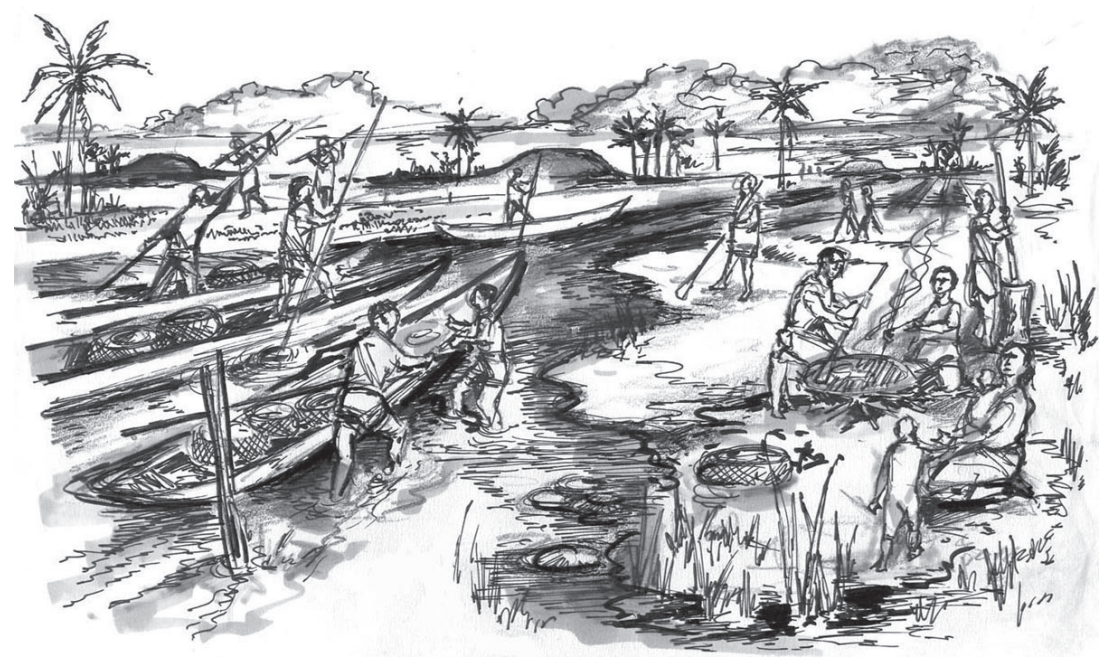

10.9 Reconstruction of use of Major Causeways-Canals in the Baures Region. (Artwork by Daniel Brinkmeier) 
artificial canals that traverse narrow sections of long forest islands, which would eliminate the need for hours of canoe portage or circumnavigation. Some of these features required considerable labor due to the volume of soil and rock excavated (Erickson, Winkler, and Candler 1997).

The density, patterning, and type of trail, path, road, and water networks may reflect the social organization, demography, and complexity of these societies. Based on their number, design, and context in the San Martin Forest Island Complex, Minor Causeways-Canals probably were constructed, used, and maintained by individual extended families or small groups of families in hamlets dispersed over adjacent forest islands (Figure 10.10). Each provided personal, direct physical connection to kin, neighbors, and friends. We can predict households and hamlets stretching along the edges of forest islands overlooking the open savanna. Fewer in number and more impressive in scale of construction, the Major Causeways-Canals connect many of the same places, but are strategically placed to efficiently connect all large forest islands with single or parallel routes.

I am convinced that the tangled mass of Minor Causeways-Canals was organized bottom-up by families, hamlets, lineages, and communities rather than imposed top-down from a central political authority. But does a single causeway-canal between two adjacent forest islands represent the work of

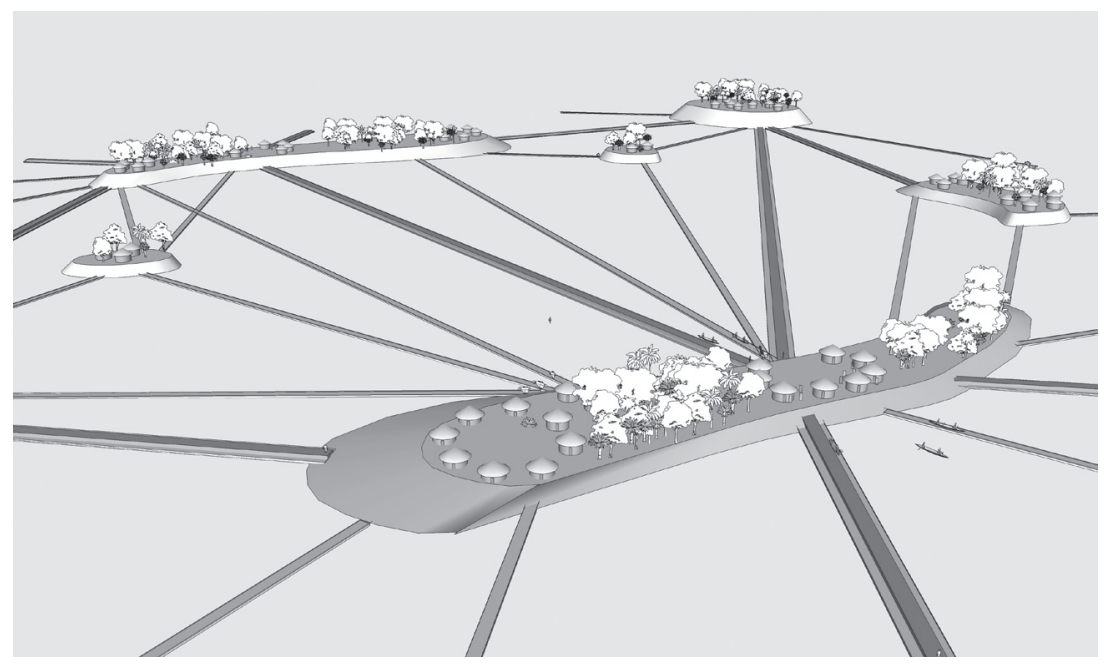

10.10 Reconstruction of the landscape of movement of the Baures Hydraulic Complex. (Artwork by Clark Erickson) 
a single household, a community, or multiple communities? If an independent community occupied each forest island, did neighboring communities collaborate on the construction and maintenance of causeways and canals? We have documented rare cases of straight Major Causeways-Canals with a slight sharp angle midway between forest islands, which may have been the result of two collaborating communities building their own half of a shared project. Some paired, parallel Major Causeways-Canals between forest islands may also represent the work of two interacting communities.

If polities beyond groups of communities existed, nested spatial patterns of interaction would be expected. Patrick Brett (2007) applied Network Analysis (e.g., Jenkins 2001) to the patterning of causeways and canals of the BHC. The analysis determines the centrality, spatial integration, hierarchy, flow, and accessibility through consideration of nodes and connections. The Degree of Centrality, which measures "centrality" of nodes on forest islands based on number of associated individual Causeways-Canals, highlighted eight important nodes. The high Degree of Centrality suggests that these locations are centers of population and social, political, and economic hierarchy. Although the most important node was expected to be located in the center of the BHC, the Degree of Centrality defines the central location as a node in the San Martin Forest Island Complex. Surprisingly, forest island size was not associated with Degree of Centrality. Other indices of Betweenness Centrality (which measures control of movement) and Closeness Centrality (which takes into consideration distance) delineate a connecting "spine" of important forest islands running northeast to southwest through the center of the BHC. Brett's analysis suggests a weakly hierarchical organization.

Another basic assumption is that the presence and density of causeways and canals map degrees of human interaction within a social network and their absence marks disjunctures, boundaries of territories, and buffer zones. Forest islands near rivers on the east and west edges of the BMC have few or no Causeways-Canals, thus may be the frontier of an integrated region of social interaction. Because of deep flooding and year-round water in the rivers, Causeways-Canals were not needed or too difficult to build. Few causeways and canals are found outside of the BHC despite similar environments. The Network Analysis and GIS suggests an interacting, bounded regional society with a diverse, densely settled population with highly structured circulation and movement.

Ethnographic analogy suggests that households and hamlets were 
capable of building and maintaining the Minor Causeways-Canals and that villages, lineages, and communities could have created the Major Causeways-Canals as public works. Ten years ago, the indigenous community of Cairo near the town of Baures built a straight causeway measuring $1 \mathrm{~km}$ to connect two forest islands in a few weeks (Figure 10.11). Although the road connected two forest islands of individual communities, the road was entirely built by the "end of the line" community to improve pedestrian and oxcart access to the town of Baures. A second causeway of $0.5 \mathrm{~km}$ was constructed between the town plaza and port on the Negro River. These grass-roots efforts by the community were also a symbol of pride and empowerment (Erickson, Winkler, and Candler 1997; Erickson 2001).

Based on our raised field experiments, profiles of earthworks, and the GIS, an estimate of labor for the 476 linear $\mathrm{km}$ of Major Causeway-Canals in the BHC is $713,864 \mathrm{~m}^{3}$ of earth moved or $1,427,727$ person-hours or 285,545 person-days. The construction of the 93.491 linear $\mathrm{km}$ of the Minor Causeway-Canals of the San Martin Forest Island Complex sample required movement of $9,349 \mathrm{~m}^{3}$ of earth that represents $18,698.2$ person-hours or 3,740 person-days. The average labor for a single Minor Causeway-Canal is 22 person-days (based on 170 Minor Causeway-Canals). A minimal unit of a family of 5 could construct a single feature in 4.4 days or two families as predicted here could do the work in 2.2 days.

Based on energetics, spatial organization and patterning, and scale, the Minor Causeways-Canals of the Baures region are a local phenomenon created through the agency of those that inhabited these locales. In the case of the Major Causeways-Canals, the overall organization was more complex and weakly hierarchically organized, but individual Major Causeways-Canals were within the capacity of communities. Based on these characteristics, the Major Causeways-Canals were created and served to integrate society at a larger scale than the more local Minor Causeways-Canals. The political organization of the Baure during the late precolumbian and early Colonial periods has often been described as a chiefdom or possibly an alliance of chiefdoms (Block 1994; Denevan 1966; Métraux 1942; Steward and Faron 1959; and others). By attributing the Minor and possibly Major CausewaysCanals to communities and smaller organizations, I do not imply that the features necessarily exist outside of chiefdoms, states, and empires. Communities and their works appear, thrive, and fail within the context of hierarchical states, globalism, failed states, and other forms of complex society. 


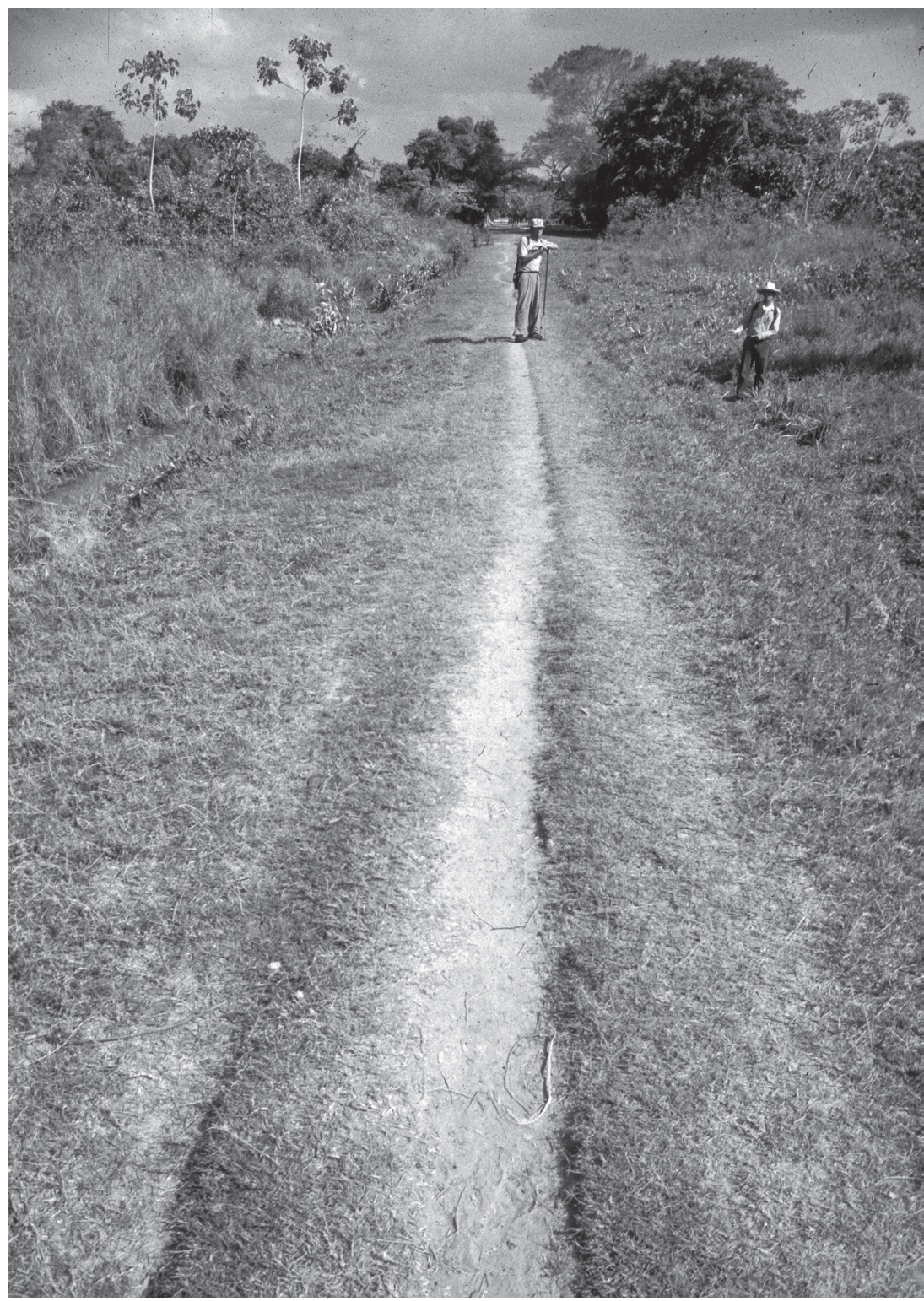

10.11 A 1-km Major Causeway-Canal built by the community of Cairo in 1994. 


\section{CONCLUSION}

The precolumbian Causeways-Canals provided basic transportation and communication, but also may have served as land tenure boundaries, water management, ideological statements about order, pride, and aesthetics, and stages for ritual events and processions for households, communities, and polities. In a society with no stone pyramids, palaces, temples, or cities, monumentality was expressed in grand avenues and canals, far beyond what was necessary for daily life in terms of number, density, redundancy, width, engineering, and complexity. These characteristics in turn imply multigenerational organization of human labor and energy to build and maintain these local, regional, and interregional scale structures.

As the result of the structures of everyday life, the Causeways-Canals of the BHC embody formal characteristics, rules, or grammar: shape, length, width, source and destination, environmental context, and straightness. As products of agency, certain variations in individual earthworks and groups of earthworks are expected. The Major Causeways-Canals were sufficient in size to permit two-way traffic, ideal for moving groups of humans at the community and intercommunity levels of organization and possibly extending to regional scale organizations. In contrast, the Minor Causeway-Canals were limited to one-way movement and more suitable for individual or small group movement between hamlets or individual households. The straightness and basic form imply a shared concept of a "proper" earthwork.

Landscapes of movement are key elements of the social reproduction of community and formation of cultural landscapes through the recursive historical relationship between agency and structure. Although treated synchronically in this chapter, the Causeways-Canals have a complex temporal dimension. Once created through human agency of repetitive movement or formal design and construction, Causeways-Canals begin to structure future movement within the cultural landscape. Placement of new Causeways-Canals had to consider previously established features that may have been used contemporaneously or been abandoned, thus invoking memory. The high density and numbers of Minor Causeway-Canals at the local level in the San Martin Forest Island Complex suggest that these features were created, used, and abandoned at a high rate, possibly during an individual's or household's lifetime. The lack of intersection or crossing of Minor and Major Causeways-Canals indicates that the builders of new 
features respected the existence of the older features. In some cases, a clear palimpsest of Minor Causeways-Canals is embedded on the landscape as a series of superimposed features. Select Minor Causeways-Canals probably became Major Causeways-Canals over time as needs and destinations of travel changed. In turn, these features channeled movement of increasingly larger groups of interacting peoples and expanded the spatial scale of interconnected movement at the subregional and regional level.

Trails, paths, and roads are the connective tissue for the threads of activities that constitute the practice of everyday life. In the case of formal engineered roads, the implications of agency and structure of movement extend into the social, political, economic, ideological, and symbolic spheres. Even ephemeral movement activity of individuals and small groups is sometime physically registered in the topography and vegetation patterning of the cultural landscape. From the local level to the regional level, the more formal means of movement are engineered and embedded into the landscape in highly visible and more permanent ways. As patterned physical features, the agency and structure of movement is amenable to archaeological investigation. Archaeologists traditionally focused on significant places or sites and their interrelationships. An archaeology of movement combined with a landscape approach and practice theory provides an exciting new perspective to understand past peoples' lives. As a produce of the dynamic interrelationship between agency and structure, trails, paths, and roads are active rather than passive cultural objects.

\section{Acknowledgments}

Fieldwork in the Baures region was conducted in 1995 and 1996 under permit from the Bolivian government to Clark Erickson and Wilma Winkler (Agro-Archaeological Project of the Beni). I thank Wilma Winkler, Alexei Vranich, Freddy Bruckner, Oscar Saavedra, Conrad Bruckner, Edwin Bruckner, Anita Bruckner, Oscar Ferrier Toledo, Hans Schlink, Kenneth Lee, Ricardo Bottega, Rodolfo Pinto Parada, and John Walker for their valuable help. Three guides, Osmar Cuellar, Jesus Zapata, and Eduardo Esero, accompanied me during fieldwork in 1996. Satellite imagery was provided by the Global Land Cover Facility and aerial photographs and topographic maps were purchased from the Military Geographic Institute and the Air Force of Bolivia. Patrick Brett helped created the GIS. Jason Ur, James Snead, and a reviewer provided useful comments. 


\section{NOTES}

1. Eder wrote in Latin. The 1888 and 1985 translations are Latin to Spanish by Armentia and Barnadas respectively. The 1973-1981 translation is from Latin to Hungarian to English by Bogler and Bognar. I have combined the best of each translation and added my own editing for clarity based on my knowledge of the causeways, canals, and local environment.

2. Burned wood from the base of the causeway was radiocarbon dated to 335 years вр (before present) \pm 20 (OS-17293) or an uncalibrated calendar date of AD 1615 (between AD 1595 and 1635). The corrected date at $68.2 \%$ confidence is AD $1490(0.26)$ AD 1530; AD 1560 (0.74) AD 1630. 